\title{
Armington Meets Melitz: Introducing Firm Heterogeneity in a Global CGE Model of Trade
}

\author{
Fan Zhai \\ Asian Development Bank Institute
}

\begin{abstract}
Traditional CGE models with Armington assumption fail to capture the extensive margin of trade, thereby underestimate the trade and welfare effects of trade opening. To address this problem, this paper introduces the Melitz (2003) theoretical framework with firm heterogeneity and fixed exporting costs into a global CGE model. Some illustrative simulations show that the introduction of firm heterogeneity improves the ability of CGE model to capture the trade expansion and welfare effects of trade liberalization. Under the case of global manufacturing tariff cut, the estimated gains in welfare and exports are more than double that obtained from the standard Armington CGE model. Sensitivity analysis indicates that model results are sensitive to the shape parameters of firm productivity distribution, suggesting the need of further empirical work to estimate the degree of firm heterogeneity.
\end{abstract}

- JEL classification: C68, F12, F17

- Key words: firm heterogeneity, CGE, trade liberalization

\section{Introduction}

Computable General Equilibrium (CGE) models have been used extensively in trade policy analysis. Despite shedding considerable light on static welfare effects and structural adjustment of trade reform around the world, however, CGE models fail to capture some important features in modern international trade. ${ }^{1}$ The most

\footnotetext{
*Fan Zhai: Asian Development Bank Institute, 3-2-5, Kasumigaseki, Chiyoda-ku, Tokyo 100-6008, Japan, Tel: +81 33593 5518, Fax: +81 33593 5571, Email: fzhai@adbi.org

(C2008-Center for International Economics, Sejong Institution, All Rights Reserved.
} 
striking one is the extensive margin, i.e. the number of exporting firms and traded goods. In the standard CGE model with Armington's (1969) national product differentiation, trade is expanded purely at the intensive margin: each exporter increases the size of its exports, but there is no change in the set of exporters. However, recent research has revealed the significant importance of the extensive margin for international trade. Empirical studies show that larger countries trade not only bigger size, but also wider variety of goods. Using data on shipment by 126 exporting countries to 59 importing countries in 5,000 product categories, Hummels and Klenow (2005) find that the extensive margin account for 60 per cent of the greater of exports of larger economies, and about one third of the greater imports of the same countries. Eaton, Kortum and Kramarz (2004) examine the firm-level export data of French firms and conclude that the number of exporting firms, rather than the amount exported by each firm, determines the variation in French exports across destinations. The extensive margin is also a crucial force to drive the trade expansion following trade liberalizations. In a study of six different trade liberalizations, Kehoe and Ruhl (2003) find that trade in goods that were not before traded shows substantial growth following a decrease in trade barriers. The set of goods that accounted for only 10 per cent of trade before the liberalization may account for 40 per cent of trade following the liberalization.

The absence of the extensive margin makes the trade CGE models incapable to explain the fast world trade growth since 1960s, leading to the quantitative puzzle of why modest decreases in tariffs generate strong expansion in trade (Bergoeing and Kehoe, 2001; Yi, 2003). For example, Kehoe (2005) uses data on actual changes in trade flows among Canada, the US and Mexico between 1988 and 1999 to evaluate the performance of three CGE models that were used in the early $1990 \mathrm{~s}$ to estimate the impacts of NAFTA. He finds that these models dramatically underestimated the impact of NAFTA on the volume of regional trade, especially for Mexico. Mexico's regional trade relative to GDP increased by over 1,000 per cent in many sectors between 1988 and 1999, while the CGE models predicted changes in trade relative to GDP of less than 50 per cent in most sectors.

The absence of the extensive margin in Armington-type CGE models also results in the well-known "stuck on zero trade" problem (Kuiper and van Tongeren, 2006). The Armington specification has the effect of locking in preexisting trade patterns and prevented the models from generating large changes in

${ }^{1}$ See Devarajan and Robinson (2005) on the influence of CGE models on trade policy and Kehoe (2005) for a critical review of CGE analysis of NAFTA. 
trade in sectors where little or no trade. Under this specification, if a country's imports of a product from another country are zero initially, they will always be zero, even after significant reductions of trade barriers. If imports are nonzero but small they will remain small even if there are large changes in prices. This "stuck on zero trade" problem makes CGE models especially inappropriate for the least developed countries which usually have limited trade with the rest of the world.

Armington models typically specify a constant elasticity of substitution (CES) utility function over the home and the import goods, under which the trade pattern is explained by the relative prices of goods produced in different regions and the fixed Armington taste (share) parameters. These fixed taste parameters, usually obtained from the calibration using observed trade flows, are essentially a black box to the model. There is no economic theory underlying the choice of these parameters. As argued by Hillberry et al. (2005), just like error terms in econometric models, the Armington taste parameters serve the role of containing the unexplained variance in the bilateral trade flows in CGE models. These "error terms" tend to be big. Hillberry et al. (2005) examine the trade patterns of 50 commodities and find the economic behavior modeled by Armington model explains less than 20 per cent of the variation in the bilateral trade flows. Thus, in Armington-type CGE models, the trade patterns are largely determined by the fixed taste parameters, but these parameters are not explained by the model.

There have been some recent efforts made toward incorporating the extensive trade margin into standard CGE models. Some of them keep the CES-based Armington structure, but seek to endogenize the Armington taste parameters. The MONASH and USAGE models developed by Monash University conduct "histrotical simulations" to estimate the historical trends in the movement of productivity and taste, and use them to update related parameters in the baseline forecasts (Dixon and Rimmer, 2002; 2003). Kuiper and van Tongeren (2006) propose to exogenously alter the Armingtion taste parameters based on separately estimated econometric gravity equations. Some CGE modelers opt for more general functional forms in place of CES functions to model import demand. For example, Robinson et al. (1993) and Weyerbrock (1998) use the AIDS function (Almost Ideal Demand System) while van der Mensbrugghe (2005) use an extended CES function with minimum demand shifters a la LES (Linear Expen- diture System) to capture the non-unitary income effects for import demand. However, none of these approaches modifies the underlying theory in any fundamental way.

The recent trade theory incorporating firm-level heterogeneity has provided an 
additional possibility to introduce the extensive margin into CGE models in a theoretically coherent way. In the models by Bernard, Eaton, Jensen and Kortum (2003), Melitz (2003), and Yeaple (2005), the patterns of trade are determined by variations in a number of factors, such as market size, number of firms, technology and trade barriers, rather than the fixed "taste" parameters. These models introduce the extensive margin as a result of the firms' self-selection to export markets. They emphasize the interaction of trade costs and productivity differences across firms operating in imperfectly competitive industries. The existence of trade costs induce only most productive firms to self-select into export markets. When trade costs decrease, new firms with lower productivity enter the export markets in response to the potential higher profits. On the other hand, the least productice non-exporting firms are forced to exit because of the increased import competition in domestic markets. Empirical evidence assembled to date has largely supported the predictions by these new firm-heterogeneity trade models. $^{2}$

An attractive feature of the new firm-heterogeneity trade models is that they provide an explicit microeconomic channel through which trade liberalization boosts aggregate productivity. Under these models, productivity gains via the reallocation of economic activity across firms within industry, as low productivity firms would exit and high productivity exporting firms would expand their market shares following the trade liberalization. The productivity effects of trade liberalization are key factors to understand the impact of trade liberalization, but, are missed in most CGE models. ${ }^{3}$

The introduction of the extensive trade margin in CGE models has important implications for evaluating the welfare effects of trade liberalization. In CGE models with national product differentiation, the simulated welfare changes of trade liberalization are dominated by the terms-of-trade effects associated with the intensive export growth, i.e. expanding export quantity but lower export price of

\footnotetext{
${ }^{2}$ Chaney (2006) estimates the distorted gravity equations based on a simplified version of Melitz (2003) model, and found strong support for it in both sectoral trade data and the stylized facts on firm-level trade. Bernard, Jensen and Schott (2006) use the firm level US manufacturing data to examine the effects of changing trade costs on firms' entry and exit behavior and changes in average productivity. They find that lowering trade costs in a sector increases the probability of firm death or entering export markets in that sector. The existing exports would expand as trade costs decline. Moreover, industry aggregate productivity and within-plant productivity rise as trade costs fall.
}

${ }^{3}$ Some CGE models incorporate ad hoc assumptions about trade-productivity externalities, such as linking productivity to export performance or imported intermediate and capital goods. See, for example, de Melo and Robinson (1992), Lewis, Robinson and Wang (1995) and World Bank (2001). 
each variety (Brown, 1987). However, as pointed out by Hummels and Klenow (2005), if export expansion is based more on the extensive margin or through quality upgrading, such adverse terms-of-trade effects are no longer a necessary consequence.

In order to improve the ability of applied trade models to describe the trade facts, this paper attempts to incorporate the recent development in heterogeneousfirm trade models into a global CGE model. Specially, I implement a firm heterogeneity global CGE model based on Melitz (2003), and carry out experimental simulations to illustrate its potential implications in the analysis of trade policy liberalization. The reminder of the paper is organized as follows: the next section presents the Melitz (2003) model. Section III discusses the specification of the heterogeneous firm CGE model and its calibration. Section IV presents the simulation results of trade liberalization using the new CGE model, and compares them to those obtained from standard Armington-type CGE model. Section V conducts sensitivity analysis. The final section offers conclusions.

\section{The Melitz Model}

The Melitz model is a dynamic industry model that incorporates the firm productivity heterogeneity into the Krugman (1979) monopolistic competition framework, and it focuses on steady state equilibrium only. The original Melitz (2003) model considers a world of symmetric countries, one factor (labor) and one industry, but it can be easily extended to the setting of asymmetric countries. ${ }^{4}$ In each country the industry is populated by a continuum of firms differentiated by the varieties they produce and their productivity. Firms face uncertainties about their future productivity when making an irreversible costly investment decision to enter the domestic market. Post-entry, firms produce with different productivity levels. In addition to the sunk entry costs, firms face fixed production costs, resulting in increasing returns to scale in production. The fixed production costs lead to exit of inefficient firms whose productivities are lower than a threshold level, as they do not expect to earn positive profits in the future. On the demand side, the agents are assumed to have Dixit-Stiglitz preference over the continuum of varieties. As each firm is a monopolist for the variety it produces, it sets the price of its product at a constant markup over its marginal cost.

${ }^{4}$ See Helpman, Melitz and Yeaple (2004) and Falvey, Greenway and Yu (2006) for extension of Melitz model to asymmetric countries. 
There are also fixed and variable costs associated with the exporting activities. But the decision to export occurs after the firms observe their productivity. Thus, a given firm enters export markets if and only if the net profits generated from its exports in a given country are sufficient to cover the fixed exporting costs. The zero cutoff profit conditions in domestic and exporting markets define the productivity thresholds for firms' entering domestic and export markets, and in turn determine the equilibrium distribution of non-exporting firms and exporting firms, as well as their average productivities. Usually, the combination of fixed export cost and variable export cost ensures that the exporting productivity threshold is higher than that associated with production for the domestic market, i.e. only a small fraction of firms with very high productivity engage in exports markets. These exporting firms supply for both domestic and export markets.

The remainder of this section describes the detailed specification of the model. For notational simplicity, the region subscript $i$ is omitted in what follows if this does not lead to confusion.

\section{(1) Demand}

There are $R$ countries in the world. In each country, the representative consumer maximizes utility from consumption over a continuum of goods $\Omega$. The utility $U$, or the aggregate good $Q$, is described by CES function, ${ }^{5}$

$$
U=Q=\left(\int_{\omega \in \Omega} q(\omega)^{\frac{\sigma-1}{\sigma}} d w\right)^{\frac{\sigma}{\sigma-1}}
$$

where $q_{\omega}$ is the quantity of consumption of good $\omega, \sigma$ is the substitution elasticity across goods. The dual price index of utility $P$ is defined over the prices of each good, $p_{\omega}$

$$
P=\left(\int_{\omega \in \Omega} p(\omega)^{1-\sigma} d w\right)^{\frac{\sigma}{1-\sigma}}
$$

And the demand for each good is

$$
q(\omega)=Q\left(\frac{P}{p(\omega)}\right)^{\sigma}
$$

\footnotetext{
${ }^{5}$ This is the standard Spence-Dixit-Stiglitz preference function which implies love of variety in utility. Some recent empirical investigations have lent support to the love of variety effects in international trade. See Broda and Weinstein (2006) and Ardelean (2007).
} 


\section{(2) Production and Trade}

There is a continuum of firms in each country, each with different productivity $\varphi$ and producing a different variety $\omega .{ }^{6}$ Production involves a fixed and variable cost, and requires only factor, labor. Trade is assumed costly. A firm must pay a fixed cost to export. In addition, there are variable trade costs, which take the form of iceberg costs whereby only a fraction $1 / \tau_{i j}$ arrives after shipping one unit of good from country $i$ to $j$ ( $\tau_{i j}=1$ for $i=j$ ). Thus, for a firm with productivity $\varphi$, the cost of producing $q$ units of good $\omega$ and selling them to country $j$ is:

$$
c\left(q_{i j}, \varphi\right)=W_{i}\left(\frac{q_{i j} \tau_{i j}}{\varphi}+f_{i j}\right)
$$

where $W_{i}$ is the wage rate and serves as numéraire. $f_{i i}$ is a fixed production input and $f_{i j}$ is the fixed input required to sell a good from country $i$ to country $j(i \neq j)$. The fixed costs are assumed to be same for all firms.

Firms are price setters. Given the demand function is isoelastic, the optimal pricing rule for firm is to charge a constant markup over marginal cost:

$$
p_{i j}(\varphi)=\frac{\sigma}{\sigma-1} \frac{\tau_{i j} W_{i}}{\varphi}
$$

The profits firm $\varphi$ in country $i$ obtains from selling in domestic market $\left(\pi_{i i}\right)$ and exporting to country $j\left(\pi_{i j}\right)$ are given by $(6)$.

$$
\pi_{i j}(\varphi)=q_{i j}(\varphi) p_{i j}(\varphi)-c\left(q_{i j}(\varphi), \varphi\right)=\frac{\left(P_{j} Q_{j}\right) P_{j}^{\sigma-1}}{\sigma}\left(\frac{\sigma-1}{\sigma} \frac{\varphi}{\tau_{i j} W_{i}}\right)^{\sigma-1}-f_{i j} W_{i}
$$

\section{(3) Entry and Exit of Firms}

The distribution of firms across different productivity levels is a result of entry and exit of firms. Prior to entry, firms are identical. To enter the industry, a firm must incur a sunk entry cost of $f_{e}$ effective labor units. After entry, firms draw their productivity, $\varphi$, from an ex-ante distribution $g(\varphi)$ with support over $(0,+\infty)$. The productivity of a firm remains fixed thereafter. However, firms will not produce if expected profits are non-positive. Thus any firm whose productivity is lower than a threshold $\varphi^{*}$ chooses to exit without even starting production. Similarly, a firm will choose to export to a given country if and only if net profits generated by the exports are sufficient to cover the fixed exporting costs. The condition defining the

${ }^{6}$ Since there is one to one correspondence between $\varphi$ and $\omega$, we shall look at the distribution of $\varphi$ instead of the distribution of $\omega$ below. 
thresholds is the zero profit cutoff condition:

$$
\varphi_{i j}^{*}=\frac{\sigma \tau_{i j}}{(\sigma-1)} \frac{W_{i}^{\frac{\sigma}{\sigma-1}}}{P_{j}}\left(\frac{f_{i j} \sigma}{P_{j} Q_{j}}\right)^{\frac{1}{\sigma-1}}
$$

where $\varphi_{i j}^{*}$ is the productivity threshold for production and $\varphi_{i j}^{*}$ is the productivity threshold for the least productive firm in country $i$ able to export to country $j$. The condition $\varphi_{i i}^{*}<\varphi_{i j}^{*}$ is assumed hold for any $j i$ to ensure the partitioning of firms by export status. The firms with productivity levels between $\varphi_{i i}^{*}$ and the lowest exporting productivity threshold $\left(\min \varphi_{i j}, j \in R, j \neq i\right.$ ) only produce for their domestic markets. The other firms vary in their exporting partners, depending on their productivity levels and the threshold $\varphi_{i j}^{*}$ in a specific exporting market.

The surviving firms are assumed to face an exogenous probability of death, $\delta{ }^{7}$ Thus the value of a firm is equal to the stream of future profits discounted by the probability of death if it draws a productivity level above the zero-profit productivity cutoff level, or equal to zero if it draws a productivity level below the cutoff level.

$$
v_{i}(\varphi)=\sum_{j \in R} \max \left\{0, \pi_{i j}(\varphi) / \delta\right\}
$$

The number of new entrants in each period is determined by the free entry condition and the general equilibrium. The free entry condition requires the expected value of entering equals the sunk cost of entering, i.e.,

$$
\int_{\varphi^{*}}^{\infty} v(\varphi) g(\varphi) d \varphi=W \cdot f_{e}
$$

And in steady state equilibrium, the mass of firms entering and producing must equal the mass of firms that die. Using $M_{e}$ to denote the mass of new entrants and $M$ to denote the mass of incumbents, the equilibrium condition is

$$
\left(1-G\left(\varphi^{*}\right)\right) M_{e}=\delta M
$$

where $G(\varphi)$ is the cumulative distribution function of $g(\varphi)$, and in $1-G\left(\varphi^{*}\right)$ is the ex ante probability of successful entry in the industry.

\section{(4) Firm Average}

In equilibrium, the weighted average productivity level of the producing firms in

${ }^{7}$ These death shocks that force firms to exit are assumed to be independent of firms' productivity. Natural disasters, new regulations and major changes in consumer tastes could be the causes of these shocks 
country $i$ as well as that for exporting firms are defined as a function of the cutoff levels, $\varphi_{i j}^{*}$ :

$$
\tilde{\varphi}_{i j}\left(\varphi_{i j}^{*}\right)=\left[\frac{1}{1-G\left(\varphi_{i j}^{*}\right)} \int_{\varphi_{i j}^{*}}^{\infty} \varphi^{\sigma-1} g(\varphi) d \varphi\right]^{1 /(\sigma-1)}
$$

where the weights reflect the relative output shares of firms with different productivity levels. ${ }^{8}$

These average productivities are also aggregate productivities because they completely summarize the information in the distribution of productivity levels for all aggregate variables. The aggregate price and demand in country $j$ and total profits earned by firms in country $i$ can also be expressed as functions of these average productivities:

$$
\begin{gathered}
P_{j}=\left(\sum_{i \in R} M_{i}\left(1-G\left(\tilde{\varphi}_{i j}\right)\right) /\left(1-G\left(\tilde{\varphi}_{i i}\right)\right)\left[p_{i j}\left(\tilde{\varphi}_{i j}\right)\right]^{1-\sigma}\right)^{\frac{1}{1-\sigma}} \\
Q_{j}=\left(\sum_{i \in R} M_{i}\left(1-G\left(\tilde{\varphi}_{i j}\right)\right) /\left(1-G\left(\tilde{\varphi}_{i i}\right)\right)\left[q_{i j}\left(\tilde{\varphi}_{i j}\right)\right]^{\frac{\sigma-1}{\sigma}}\right)^{\frac{\sigma}{\sigma-1}} \\
\Pi_{i}=\sum_{j \in R} M_{i}\left(1-G\left(\tilde{\varphi}_{i j}\right)\right) /\left(1-G\left(\tilde{\varphi}_{i i}\right)\right) \pi_{i j}\left(\tilde{\varphi}_{i j}\right)
\end{gathered}
$$

\section{(5) Equilibrium}

In each country, the representative consumer supplies $L$ units of labor. The equilibrium in labor market requires that:

$$
L_{i}=L_{p i}+L_{e i}=\sum_{j} q_{i j}\left(\check{\varphi}_{i j}\right) / \check{\varphi}_{i j}+\sum_{j \in R} M_{i}\left(1-G\left(\tilde{\varphi}_{i j}\right)\right) /\left(1-G\left(\tilde{\varphi}_{i j}\right)\right) f_{i j}+M_{e} f_{e i}(15)
$$

where $L_{p}$ is the labor input for production and $L_{e}$ is that used in investment by new entrants.

The representative consumer receives labor income and profits, and spends on consumption $Q$ and irreversible investment $f_{e}$. As the free entry ensures that total profits are exhausted by the aggregate investment sunk costs of new entrants, i.e., $L_{e i}=M_{e i} f_{e i}=\delta M_{i} /\left(1-G\left(\varphi_{i i}^{*}\right)\right) f_{e i}=\Pi_{i}$, the budget constraint of consumer is $W \cdot L=P \cdot Q$. This budget constraint also determines the equilibrium in goods market

${ }^{8}$ See footnote 9 of Melitz (2003). 
in each country.

\section{(6) Properties of the Equilibrium}

Some properties of the equilibrium of the Meltiz model are worthy mentioning. ${ }^{9}$ First, trade opening leads to reallocation of market shares and profits among firms. Falling trade costs increases the profits of exporting firms and lowers the exporting productivity threshold. As a result, new and less productive firms enter the export markets. Moreover, reduction of trade costs enables existing exporting firms to increase their sales to foreign markets. In domestic market, more competition from increased imports results in domestic firms losing a portion of their domestic markets. On the other hand, the expansion of existing high productivity firms for exports and the entry of new firms increase labor demand, driving up real wage. Reduced profits and rising costs make the less productive firms unable to survive, forcing them to exit. As a result, the most productive firms increase their market shares and profits, while the least productivity firms shrink or exit. Thus, trade opening leads to larger inequalities between firms.

Second, because of the intra-industry resource reallocation, trade liberalization will unambiguously increase aggregate productivity in all trading economies. The reallocation of market shares towards exporting firms can boost the aggregate productivity as exporting firms are more productive. The entry of new exporters may also increase average productivity if the new entrants are more productive than the average productivity level. Average productivity in importing country is also enhanced because of the exit of the least productive non-exporting firms.

Third, trade liberalization always generates a welfare gain in the model. The magnitude of the gain is determined by the interaction of three factors: the decreased number of domestic firms, the increased number of foreign exporters and the increased average productivity of domestic firms. The less number of domestic firms supplied to domestic markets causes negative variety effect for domestic consumers. But this effect is typically dominated by the increased number of new foreign exporters, thereby domestic consumers still enjoy greater product variety. If a larger number of domestic firms are replaced by foreign firms and product variety impacts negatively on welfare, the positive contribution of aggregate productivity gain would more than offset the loss in variety. The net welfare gain from trade liberalization is always positive.

\footnotetext{
${ }^{9}$ See Melitz (2003) for detailed exploration and proof of these properties.
} 


\section{A Global CGE Model with Heterogeneous Firms}

I now turn to a specific global CGE model with heterogeneous firms. The CGE model consists of 12 regions, 14 sectors and 5 production factors. Within the 14 sectors, agriculture and energy sectors produces homogeneous products. In each of these two sectors, there is a representative firm operated under constant returns to scale technology. The other 12 manufacturing and services sectors produce differentiated products. In these sectors, the production and trade structures of the CGE model closely follow the Melitz model in section II, but with two modifications. First, similar to Chaney (2006), I abstract from the dynamic parts of the Melitz model by assuming no entry and exit of firms, no sunk entry costs and no uncertainty about productivity before entry. Thus the CGE model characterizes a static equilibrium, rather than a steady state equilibrium. This abstraction is mainly due to the computational difficulties associated with multiple corner equilibria that the Melitz model may exhibit when it is extended to a multi-sector and asymmetric country setting and the intermediate inputs are explicitly considered. The centripetal forces arising from the self-reinforcing forward and backward linkages cause the multiple corner equilibria, and lead the model to behave more like a New Economic Geography model. ${ }^{10}$ Second, the CGE model assumes no fixed production costs, but fixed domestic trading costs are assumed in those sectors with heterogeneous firms. The presence of fixed trading costs leads to increasing returns to scale technology in these sectors. This assumption makes the model more readily compatible with the case in which the number of exporting firms is larger than that of firms serving solely their domestic market. Although empirical evidence at the aggregate level strongly supports selection into export markets, there may be in some particular sectors with data pointing to the other direction. ${ }^{11}$

\section{(1) Demand}

In each region of the model, the representative consumer receives income from

\footnotetext{
${ }^{10}$ The centripetal forces and multiple equilibria are central themes of new economic geography models which analyze industry's location decisions in the context of imperfect competition and economies of scale. See Fujita et al. (1999).

${ }^{11}$ See Bernard ad Jensen (1999, 2004), Roberts and Tybout (1997) and Clerides et al. (1998) for empirical evidence on selection into export markets. The electronic component sector in China and some Southeast Asian countries may be good counterexamples for selection into export markets. As part of the global supply chain and regional production network, a large proportion of their products are exported and some of their firms are fully export-oriented.
} 
the supply of production factors to the firms, dividends from the firms and lumpsum transfers from the government. They allocate their disposable income among the consumer goods and saving using the extended linear expenditure system, which is derived from maximizing a Stone-Geary utility function. ${ }^{12}$ The consumption/ saving decision is completely static. Saving enters the utility function as a "good" and its price is set equal to the average price of consumer goods.

Investment demand and government consumption are specified as Leontief function. I assume in each sector $s$ a composite good $Q_{s}$ is used for household consumption, investment, government consumption and intermediate input. The composite good is a CES aggregation of domestic goods and imports.

$$
Q_{j}^{s}=\left(\sum_{i \in R}\left(\alpha_{i j}^{s}\right)^{1 / \sigma^{s}}\left(Z_{i j}^{s}\right)^{\left(\sigma^{s}-1\right) / \sigma^{s}}\right)^{\sigma^{s} /\left(\sigma^{s}-1\right)}
$$

where $Z_{i j}^{s}$ is the quantity of good $s$ produced in region $i$ sold in the market of region $j$. The dual price index of composite $\operatorname{good} s, P_{j}^{s}$, is defined over the aggregate prices of each supplier, $P_{r i j}^{s}$

$$
P_{j}^{s}=\left(\sum_{i \in R} \alpha_{i j}^{s}\left(P_{r i j}^{s}\right)^{1-\sigma^{s}}\right)^{1 /\left(1-\sigma^{s}\right)}
$$

And the demand function generated from (21) is:

$$
\frac{Z_{i j}^{s}}{Q_{j}^{s}}=\alpha_{i j}^{s}\left(\frac{P_{j}^{s}}{P_{r i j}^{s}}\right)^{\sigma}
$$

In sectors with homogeneous goods, I follow the standard Armington assumption of national production differentiation, thus $\sigma^{s}$ represents the substitution elasticity of good $s$ among different regions in these sectors. The Armington share parameters $\alpha_{i j}^{s}$ in these sectors reflect the preference of consumers biasing for home or other regions' products. In sectors with differentiated goods, $\sigma^{s}$ represents the substitution elasticity among variety of each firm and $Z_{i j}^{s}$ is the CES aggregate of the individual varieties that are produced in country $i$ and sold in region $j$. In these sectors, Armington share parameters $\alpha_{i j}^{s}$ always equal to one, rendering that the pattern of bilateral trade flows in these sectors are totally determined by the relative prices of aggregated differentiated goods from each region, $P_{r i j}^{s}$.

\footnotetext{
${ }^{12}$ The modeling of households behavior follows the LINKAGE model. See van der Mensbrugghe (2005).
} 


\section{(2) Production and Trade}

Factor markets: There are five primary factors: capital, skilled labor, unskilled labor, agricultural land and natural resources for mining sector. Factor endowments are assumed to be fully employed. Land and natural resources are sector-specific but capital and labor are fully mobile across sectors. All primary factors are immobile across countries.

Production technology: Production is modeled using a nesting of CES functions. In the top level, the output $X^{s}$ is produced as a combination of aggregate intermediate demand and value added. In the second level, aggregate intermediate demand is split into each commodity according to Leontief technology. Value added is produced by capital-land bundle and aggregate labor. Finally, in the bottom level, aggregate labor is decomposed into unskilled and skill labor, and capital-land bundle is decomposed into capital and land (for agriculture sector) or natural resources (for mining sector). In each level of productions, there are a unit cost function that is dual to the CES aggregator function and demand functions for corresponding inputs. The top level unit cost function defines the marginal cost of sectoral output, $C^{s}$.

Firm heterogeneity: In each region and sector the total mass of potential firms, $N_{i}^{s}$, is fixed. Firms are assumed to get a productivity draws $\varphi$ from a Pareto distribution with low bound $\varphi_{\min }$ and shape parameter $\gamma \gamma-1 .{ }^{13}$ Without loss of generality, the units of quantity can be chosen so that the low bound parameter $\varphi_{\min }$ equals unity. Then the density function $g(\varphi)$ and the cumulative distribution function $G(\varphi)$ are:

$$
g(\varphi)=\gamma \varphi^{-\gamma-1}, \quad 1-G(\varphi)=\varphi^{-\gamma}, \quad \varphi \in[1, \infty)
$$

$\gamma$ is an inverse measure of the firm heterogeneity. The higher $\gamma$, the more homogeneous the firms are. Firms do not need to pay a sunk cost to participate in the productivity draw. With the Pareto distribution, the average productivities for non-exporting firms in county $i$ and firms in country $i$ exporting to country $j, \varphi_{i j}^{s}$, can be expressed as:

$$
\tilde{\varphi}_{i j}^{s}=\varphi_{i j}^{s *}\left(\frac{\gamma_{i}^{s}}{\gamma_{i}^{s}-\sigma^{s}+1}\right)^{1 /\left(\sigma^{s}-1\right)}
$$

where $\varphi_{i j}^{s^{*}}$ is the productivity thresholds for firms in region $i$ entering market $j$.

Fixed trading costs: In addition to variable costs, firms in the sectors with heterogeneous firms face region-specific fixed costs for their domestic sales and

\footnotetext{
${ }^{13}$ The assumption that $\gg \sigma-1$ ensures that the size distribution of firms has a finite mean.
} 
exports. The fixed inputs of these firms are fixed combination of capital $\left(f_{K i j}^{s}\right)$, labor $\left(f_{L i j}^{s}\right)$ and intermediate inputs $\left(f_{X i j}^{t s}\right)$. Thereby the expenditure of fixed trading costs, $F_{i j}$, are defined as:

$$
F_{i j}^{s}=W_{i} f_{L i j}^{s}+R_{i} f_{K i j}^{s}+\sum_{t} P_{i}^{t} f_{X i j}^{t s}
$$

where $W_{i}, R_{i}$, and $P_{i}^{t}$ are wage rate, rental rate of capital and price of good $t$, respectively.

Pricing and cut-off productivity: The model assumes "large group" monopolistic competition under that the number of firms is arbitrarily large, such that the elasticity of demand for each firm's output is the substitution elasticity among varieties, $\sigma$. This results in fixed markup as in (5). Then the variety adjusted aggregate prices of domestic sale and exports can be defined as:

$$
P_{r i j}^{s}=\frac{\sigma^{s}}{\sigma^{s}-1} \frac{\left(1+t_{i j}^{s}\right) \tau_{i j}^{s} C_{i}^{s}}{\tilde{\varphi}_{i j}^{s}}\left[N_{i}^{s}\left(1-G\left(\varphi_{i j}^{s *}\right)\right)\right]^{1 /\left(1-\sigma^{s}\right)}
$$

where $t_{i j}^{s}$ is tariff rate, and $\tau_{i j}^{s}$ is ice-berg type variable trade cost and $N_{i}^{s}\left(1-G\left(\varphi_{i j}^{s *}\right)\right)$ represents the total mass of firms in sector $s$ and region $i$ that sell in market $j$.

In sectors producing homogeneous goods, the markup is zero and productivity is fixed and normalized to one. Their producer prices are simply equal to marginal costs.

$$
P_{r i j}^{s}=\left(1+t_{i j}^{s}\right) \tau_{i j}^{s} C_{i}^{s}
$$

In sectors with heterogeneous firms, the productivity thresholds for market entry and exporting are:

$$
\varphi_{i j}^{s *}=\frac{\sigma^{s} \tau_{i j}^{s} C_{i}^{s}}{\left(\sigma^{s}-1\right)}\left(\frac{P_{j}^{s}}{1+t_{i j}^{s}}\right)^{\frac{\sigma^{s}}{1-\sigma^{s}}}\left(\frac{F_{i j}^{s} \sigma^{s}}{Q_{j}^{s}}\right)^{\frac{1}{\sigma^{s}-1}}
$$

The total profits of firms in sector $s$ and region $i, \Pi_{i}^{s}$, is the residual between the revenue from sales and all production and trading costs.

$$
\begin{aligned}
\Pi_{i}^{s} & =\sum_{j \in R}\left(P_{r i j}^{s} Z_{i j}^{s} /\left(1+\tau_{i j}^{s}\right)-N_{i}^{s}\left(1-G\left(\varphi_{i j}^{*}\right)\right) F_{i j}^{s}\right)-C_{i}^{s} X_{i}^{s} \\
& =\sum_{i \in R} \frac{P_{r i j}^{s} Z_{i j}^{s}}{\left(1+\tau_{i j}^{s}\right)} \frac{1}{\sigma^{s}} \frac{\sigma^{s}-1}{\gamma_{i}^{s}}
\end{aligned}
$$




\section{(3) Equilibrium and Closure}

Equilibrium in the goods markets requires that the output, $X_{i}^{s}$, equals the sum of demands in each market, i.e.:

$$
X_{i}^{s}= \begin{cases}\sum_{j \in R} \frac{z_{i j}^{s}}{\tau_{i j}^{s}} & \text { for sectors with a representative firm } \\ \sum_{j \in R}\left[N_{i}^{s}\left(1-G\left(\varphi_{i j}^{s *}\right)\right)\right]^{1 /\left(1-\sigma^{s}\right)} \frac{Z_{i j}^{s}}{\tau_{i j}^{s} \tilde{\varphi}_{i j}^{s}}, & \text { for sectors with heterogeneous firms }\end{cases}
$$

Note that for sectors with heterogeneous firms, demands are adjusted by the DixitStiglitz variety effects and the average productivity.

There are three closure rules - the net government balance, investment-savings, and the trade balance. I assume that changes in the government budget are automatically compensated by changes in marginal income tax rates. Government expenditures are exogenous in real terms.

Domestic investment is identically equal to the sum of domestic saving resources, i.e., household saving, government saving, and net foreign saving. As government saving is exogenous, changes in investment are determined by changes in the levels of household saving and foreign saving.

The final closure rule concerns the current account balance. In each region, either the foreign saving or real exchange rate can be fixed while the other is allowed to adjust providing alternative closure rules. When foreign saving set exogenously, the price index of global manufacturing exports is chosen as the numéraire and the equilibrium is achieved through changing the relative price across region, i.e. the real exchange rate. Alternatively, the GDP price deflator in each region is fixed and the foreign saving is endogenous (subjecting to the constraint of the global balance) to maintain the trade balance. In the simulations conducted in section IV and V, the foreign saving is chosen to be fixed and the manufacturing export price index is the numéraire.

\section{(4) Calibration}

The model is calibrated to the GTAP (version 6.2) global database. However, some of the information that is central to our model, such as the degree of returns to scale, the shape of the productivity distribution, and the magnitude of the fixed and variable trade cost, are not available in the GTAP database. I set these 
Table 1. Major Parameters in the Model

\begin{tabular}{lccc}
\hline & $\begin{array}{c}\text { Markup } \\
\text { ratio }\end{array}$ & $\begin{array}{c}\text { Substitution } \\
\text { elasticity between } \\
\text { varieties }\end{array}$ & $\begin{array}{c}\text { Shape parameter } \\
\text { in productivity } \\
\text { distribution }\end{array}$ \\
\hline Processing food & $20 \%$ & 6.0 & 7.75 \\
Textile & $20 \%$ & 6.0 & 7.75 \\
Apparels & $20 \%$ & 6.0 & 7.75 \\
Material & $20 \%$ & 6.0 & 7.75 \\
Chemical & $25 \%$ & 5.0 & 6.20 \\
Electronics and electrical equipment & $25 \%$ & 5.0 & 6.20 \\
Vehicles & $25 \%$ & 5.0 & 6.20 \\
Machinery & $25 \%$ & 5.0 & 6.20 \\
Other manufacturing & $25 \%$ & 5.0 & 6.20 \\
Trade, transportation and communication & $30 \%$ & 4.3 & 5.17 \\
Other services & $30 \%$ & 4.3 & 5.17 \\
\hline
\end{tabular}

parameters mainly based on a review of the relevant literature. Table 1 reports some major parameters used in the model. The markup ratios are set equal to 20-25 per cent for manufacturing sectors and 30 per cent for services sectors. The choice of markup ratios, together with optimal pricing rule of monopolistic firms, imply that the substitution elasticity between differentiated varieties is 6.0 for manufacturing sectors and 5.0 for services sectors. Firm productivity is assumed to follow Pareto distribution. The shape parameters of the Pareto distribution are calibrated to match the profit ratio in total markup, which is estimated to be 64.5 per cent based on French firm data by Arkolakis (2006). Assuming that all regions have access to same technology, the marginal costs $C$ are set equal to unity in all regions for the calibration.

I assume the mass of potential firms in each sector, $N_{i}^{s}$, is proportional to the sectoral output. As fixed production cost, fixed exporting costs and variable trade costs are not available, they are calibrated to the base year bilateral trade flows. From the demand function in (18), and using the price function (22), average productivity function (20) and cut-off productivity function (24), we have the following gravity equation determining the bilateral trade flows:

$$
P_{r i j}^{s} Z_{i j}^{s}=\left(P_{j}^{s} Q_{j}^{s}\right)^{\varkappa_{i} /\left(\sigma^{s}-1\right)} N_{i}^{s}\left(\frac{P_{j}^{s}}{\left(1+t_{i j}^{s}\right) \tau_{i j}^{s} C_{i}^{s}} \frac{\sigma^{s}-1}{\sigma^{s}}\right)^{\varkappa_{i j}}\left(F_{i j}^{s}\left(1+t_{i j}\right) \sigma^{s}\right)^{1-\varkappa_{i} /\left(\sigma^{s}-1\right)} \frac{\gamma_{i}^{s}}{\gamma_{i}^{s}-\sigma^{s}+1}
$$


This equation reflects the combined effects of market size $\left(P_{j} Q_{j}\right)$, stiffness of market competition (reflected in $P_{j}$ ), technology $\left(C_{i}\right)$, number of potential firms $\left(N_{i}\right)$ and trade barriers $\left(t_{i j}, \tau_{i j}\right.$, and $\left.F_{i j}\right)$ on bilateral trade patterns. By replacing the variable export costs $\tau_{i j}$ with the share of exporting firms $\left(1-G\left(\varphi_{i j}^{s *}\right)\right),(27)$ can be rewritten as:

$$
P_{r i j}^{s} Z_{i j}^{s}=N_{i}^{s}\left(1-G\left(\varphi_{i j}^{s *}\right)\right)\left(F_{i j}^{s}\left(1+t_{i j}\right) \sigma^{s}\right) \frac{\gamma_{i}^{s}}{\gamma_{i}^{s}-\sigma^{s}+1}
$$

Based on the empirical findings in Hummels and Klenow (2005), I assume that extensive margin accounts for 60 per cent of the difference in export values across regions, i.e.

$$
\left(\frac{P_{r i j}^{s} Z_{i j}^{s}}{P_{r j j}^{s} Z_{j j}^{s}}\right)^{0.6}=\frac{N_{i}^{s}\left(1-G\left(\varphi_{i j}^{s *}\right)\right)}{N_{j}^{s}\left(1-G\left(\varphi_{j j}^{* *}\right)\right)}
$$

Assuming 60 per cent of potential firms produce and sell in the domestic market, the shares of exporting firms can be calculated from (29) using the base year trade flows and domestic sales data. The fixed trading costs can also be derived from (28). Given that the shares of firms selling in each market are determined, one can solve their productivity thresholds from (19). I also assume that domestic trade incurs no iceberg costs, i.e. $\tau_{i i}$ equals 1 . The iceberg international trade costs $\tau_{i j}$ can thus be obtained from (24).

Zero-trade flows are frequently present in international trade databases, including the GTAP database. Under Armington trade structure, the share parameters $\alpha_{i j}^{s}$ are zero if there is no trade between their corresponding trading partners. However, for the sectors with heterogeneous firms, the zero-trade flow is not allowed in the model because of (i) the unitary import share parameters $\alpha_{i j}^{s}$ for all trade partners, and (ii) the infinity upper bound of firms' productivity distribution. To resolve this dilemma, I modify benchmark trade data by assigning an arbitrarily small value to initial zero-trade cells. This tiny base year trade value leads to very high calibrated fixed and variables trade costs for corresponding trade partners.

\section{Simulations}

To explore the properties of the firm-heterogeneity CGE model, I run several trade liberalization simulations and contrast the outcomes of the model to a benchmark standard Armington CGE model with homogeneous firms. The first 
Table 2. Welfare Effects of Trade Liberalization (EV, billion 2001 US\$)

\begin{tabular}{lccccc}
\hline \multicolumn{2}{c}{$50 \%$ tariffs cut } & \multicolumn{2}{c}{$\begin{array}{c}5 \% \text { reduction in } \\
\text { variable trade costs }\end{array}$} & $\begin{array}{c}50 \% \text { reduction in } \\
\text { fixed exporting costs }\end{array}$ \\
& $\begin{array}{c}\text { Firm } \\
\text { heterogeneity } \\
\text { model }\end{array}$ & $\begin{array}{c}\text { Armington } \\
\text { model }\end{array}$ & $\begin{array}{c}\text { Firm } \\
\text { heterogeneity } \\
\text { model }\end{array}$ & $\begin{array}{c}\text { Armington } \\
\text { model }\end{array}$ & $\begin{array}{c}\text { Firm } \\
\text { heterogeneity } \\
\text { model }\end{array}$ \\
\hline USA & 3.5 & 4.4 & 32.8 & 44.8 & 44.3 \\
EU & 16.6 & 10.2 & 128.2 & 125.0 & 144.1 \\
Australia \& & 2.2 & 1.1 & 5.0 & 4.8 & 5.5 \\
N. Zealand & 15.6 & 7.6 & 11.7 & 13.4 & 13.3 \\
Japan & 8.5 & 3.9 & 21.3 & 17.0 & 24.0 \\
NIEs & 5.3 & 2.2 & 18.0 & 16.1 & 18.6 \\
China & 9.8 & 3.7 & 32.7 & 16.9 & 34.6 \\
ASEAN & 5.9 & 2.9 & 3.7 & 3.6 & 3.8 \\
India & 0.9 & 0.3 & 2.3 & 2.1 & 2.5 \\
Rest of Asia & 0.2 & 0.3 & 27.0 & 24.0 & 32.9 \\
Latin America & 1.8 & 1.4 & 9.7 & 8.6 & 9.7 \\
Africa & 4.8 & 4.3 & 35.9 & 34.3 & 38.7 \\
Rest of the World & 75.0 & 42.2 & 328.3 & 310.6 & 372.0 \\
Total & & & & & \\
\hline & & & & & \\
\hline
\end{tabular}

simulation lowers global manufacturing tariffs by 50 per cent. The second simulation reduces variable trade costs $\tau_{i j}^{s}$ in manufacturing sectors by 5 per cent. The third simulations cut fixed exporting costs in manufacturing sectors by 50 per cent. Table 2 shows the welfare effects of these trade liberalization experiments. The results of first two simulations from a standard homogeneous firm CGE model are also reported in Table $2 .^{14}$

The firm heterogeneity CGE model predicts a global welfare gain of $\$ 75.0$ billion from the 50 per cent global manufacturing tariff cut, nearly double of the estimate came out from standard Armington CGE model. The difference between the two models in welfare results from simulation of variable trade cost reductions is less prominent. A 5 per cent reduction in variable trade costs of manufacturing sectors would lead to $\$ 328.3$ billion global welfare gains in firm heterogeneity model, in contrast to the estimate of $\$ 310.6$ billion from Armington CGE model.

\footnotetext{
${ }^{14}$ For the sake of comparability, I do not use the GTAP values of Armington elasticities in manufacturing and services sectors in the standard homogeneous firm CGE and instead use the same values of the substitution elasticity between differentiated varieties in the firm heterogeneity model as shown in Table 1.
} 
However, it is important to mention here that tariff and iceberg trade costs are different in nature: tariffs represent money transfers while iceberg trade costs actually burn up resources. As global manufacturing exports account for 16 per cent of world GDP, a 5 per cent reduction in their variable trade costs would bring a direct efficiency gain of 0.8 per cent of world GDP. If this part is excluded, the indirect welfare gains of variable trade costs reduction would be US $\$ 58.9$ billion for the firm heterogeneity model and US\$41.2 billion for Armington CGE model, still showing a relatively large difference between the two models. The results in Table 1 also suggest that the welfare effects of cutting fixed exporting costs are significant - a 50 per cent cut in manufacturing fixed exporting costs brings five times larger gains than that arising from same percentage reduction in tariffs.

Compared with the standard Armington, CGE model with constant returns to scale technology and homogeneous firms, the firm heterogeneity model introduces three additional channels through which the trade liberalization yields welfare gains. The first is the Dixit-Stiglitz "love-of-variety effect", i.e. the welfare gains from the entry of firms and associated increase in variety. Trade liberalization tends to increase the number of exporting firms and leads to greater product variety for domestic consumers if the losses in the number of domestic suppliers are more than offset by the number of new foreign exporters. The second channel is the productivity gains from intra-industry resource reallocation explained in section II. This is a unique channel in firm heterogeneity model, as the productivity is taken as given in either Armington model or the Krugman (1979) new trade theory model. The third channel is the scale effects. Increased import competition drives out the inefficient domestic producer and results in less producing firms. Due to increasing returns to scale, average costs usually fall even they are partly offset by the increased fixed exporting costs associated with a larger number of exporting firms. ${ }^{15}$

Table 3 and 4 report the changes of firm numbers and average productivity in aggregated manufacturing sector under the three trade liberalization simulations. As predicted by the theoretical model, trade liberalization leads to fewer domestic firms, but facilitates more firms engaging in exporting activities. In the tariff reduction simulation, regions with high initial tariff rates (Africa, India) experience larger decreases in the number of domestic firms. But the number of exporting

\footnotetext{
${ }^{15}$ To ensure the new model generates additional gains from trade expansion in comparison with the conventional model, I raise the Armington elasticities in the standard Armington CGE model by 33 per cent and run the tariff reduction simulation. Compared to the Melitz CGE model, the Armington CGE model with high elasticities predicts similar expansion in global real exports, but 23 per cent lower global welfare gains. I am grateful to Peter Dixon for suggesting this simulation.
} 
Table 3. Changes in Numbers of Firms (\%)

\begin{tabular}{lcccccc}
\hline & \multicolumn{3}{c}{ Domestic Firms } & \multicolumn{3}{c}{ Exporting Firms } \\
\hline & $\begin{array}{c}50 \% \\
\text { tariffs } \\
\text { cut }\end{array}$ & $\begin{array}{c}5 \% \\
\text { reduction } \\
\text { in variable } \\
\text { trade costs }\end{array}$ & $\begin{array}{c}50 \% \\
\text { reduction } \\
\text { in fixed } \\
\text { exporting costs }\end{array}$ & $\begin{array}{c}\text { tariffs } \\
\text { cut }\end{array}$ & $\begin{array}{c}5 \% \\
\text { reduction } \\
\text { in variable } \\
\text { trade costs }\end{array}$ & $\begin{array}{c}\text { reduction in } \\
\text { fixed exporting } \\
\text { costs }\end{array}$ \\
\hline USA & -2.2 & -8.8 & -9.4 & 6.4 & 22.8 & 151.3 \\
EU & -3.0 & -15.4 & -16.6 & 3.5 & 16.9 & 129.0 \\
Australia \& & -7.2 & -12.9 & -13.9 & 24.5 & 24.4 & 146.1 \\
N. Zealand & -1.9 & -5.7 & -6.4 & 11.9 & 15.5 & 139.7 \\
Japan & -5.1 & -14.1 & -16.1 & 14.3 & 22.9 & 144.2 \\
NIEs & -6.5 & -6.5 & -7.1 & 24.7 & 19.1 & 143.4 \\
China & -7.2 & -6.7 & -9.4 & 12.6 & 35.4 & 154.2 \\
ASEAN & -15.8 & -7.1 & -7.9 & 56.1 & 18.8 & 128.9 \\
India & -7.7 & -6.8 & -7.5 & 40.1 & 23.3 & 132.6 \\
Rest of Asia & -5.8 & -7.7 & -8.4 & 19.3 & 25.1 & 131.4 \\
Latin America & -17.7 & -13.2 & -13.9 & 32.5 & 24.0 & 110.7 \\
Africa & -7.3 & -12.7 & -14.0 & 11.6 & 23.8 & 128.7 \\
Rest of the World & & & & & &
\end{tabular}

Table 4. Changes in Manufacturing Average Productivity (\%)

\begin{tabular}{lcccccc}
\hline & \multicolumn{3}{c}{ Domestic Suppliers } & \multicolumn{3}{c}{ All Producing Firms } \\
\hline & $\begin{array}{c}50 \% \\
\text { tariffs } \\
\text { cut }\end{array}$ & $\begin{array}{c}5 \% \\
\text { reduction } \\
\text { in variable } \\
\text { trade costs }\end{array}$ & $\begin{array}{c}50 \% \\
\text { reduction } \\
\text { in fixed } \\
\text { exporting costs }\end{array}$ & $\begin{array}{c}50 \% \\
\text { tariffs } \\
\text { cut }\end{array}$ & $\begin{array}{c}5 \% \text { reduction } \\
\text { in variable } \\
\text { trade costs }\end{array}$ & $\begin{array}{c}50 \% \\
\text { reduction in } \\
\text { fixed exporting } \\
\text { costs }\end{array}$ \\
\hline USA & 0.3 & 1.3 & 1.4 & 0.6 & 2.0 & -0.4 \\
EU & 0.5 & 2.2 & 2.3 & 0.8 & 1.3 & -3.5 \\
Australia \& & 1.1 & 2.0 & 2.1 & 0.0 & 1.2 & -2.0 \\
N. Zealand & 0.4 & 0.8 & 0.9 & 0.8 & 1.1 & -1.6 \\
Japan & 0.9 & 2.2 & 2.4 & 0.3 & 1.0 & -4.1 \\
NIEs & 1.0 & 0.9 & 1.0 & 1.2 & 1.0 & -1.8 \\
China & 1.9 & 2.2 & 2.3 & 0.2 & -1.0 & -7.4 \\
ASEAN & 2.6 & 1.0 & 1.1 & 2.3 & 1.1 & -0.7 \\
India & 1.2 & 1.0 & 1.1 & 0.7 & 0.8 & -1.1 \\
Rest of Asia & 0.8 & 1.0 & 1.1 & 0.9 & 1.0 & -1.1 \\
Latin America & 2.8 & 1.9 & 1.9 & 1.5 & 1.1 & -1.4 \\
Africa & 1.2 & 1.8 & 1.9 & 1.3 & 1.4 & -1.8 \\
Rest of the World & & & & & & \\
\hline
\end{tabular}


firms also expands most due to their small numbers of exporting firms in the preliberalization equilibrium. The reduction of variable trade costs results in relatively even increases in exporting firms across all the regions. But its impact on the number of domestic firms is different. Regions more open to international trade or less competitive in manufacturing sectors experience larger decreases in their numbers of domestic firms. The impact of a reduction in fixed exporting costs on the number of exporting firms is quite large. For most regions, their number of exporting firms would increase by 110-155 per cent.

Table 4 indicates that the productivity gains from a 50 per cent cut in manufacturing tariffs are sizeable for Africa and India, whose average productivity of domestic suppliers in manufacturing sector rise by 2.8 per cent and 2.6 per cent respectively. The US, Japan and EU would gain only modestly in productivity given their already low manufacturing tariffs. However, sector-wide average productivity is also impacted by the entry and output expansion of exporting firms. In the cases of Australia and New Zealand, NIEs, ASEAN and Africa, because of their relatively high ratios of exporting firms in manufacturing sector, the new entrants of exporting firms are less efficient and their entry causes smaller gains in average productivity of all producing firms relative to that of domestic suppliers. For the other regions, new exporting firms are more efficient than the industry average, and thus contribute to a further rise in sector-wide average productivity.

The productivity gains for domestic suppliers from a 5 per cent reduction of variable trade costs range from 0.8 (Japan) to 2.2 (EU, NIEs and ASEAN). This estimate is smaller than the 4.7 per cent productivity increase obtained by Bernard, Eaton, Jensen and Kortum (2003) for the US who use a probabilistic Ricardian model with Bertrand competition to consider the same percentage drop in world trade barriers. However, the result is more or less consistent with a recent study by Del Gatto, Mion and Ottaviano (2006), who calibrate a multi-country multi-sector firm heterogeneity model based on Melitz and Ottaviano (2005) to 11 EU countries and find that a 5 per cent reduction in intra-EU trade costs would generate an average productivity gain of 2.13 per cent for the EU countries.

One last thing that needs to be discussed is the trade volume effect of trade liberalization. Table 5 reports the changes in real exports under the trade liberalization simulations, and again, contrasts them with the results from standard Armington CGE model. ${ }^{16}$ Generally, the trade expansion induced by trade liberali-

\footnotetext{
${ }^{16}$ The real exports are defined as the sum of each firm's exports, i.e. they are measured "at the factory gate" and not augmented by variety effects.
} 
Table 5. Effects of Trade Liberalization on Export Values (\%)

\begin{tabular}{lccccc}
\hline & \multicolumn{2}{c}{$50 \%$ tariffs cut } & $\begin{array}{c}5 \% \text { reduction in } \\
\text { variable trade costs }\end{array}$ & $\begin{array}{c}\text { 50\% reduction in } \\
\text { fixed exporting costs }\end{array}$ \\
& $\begin{array}{c}\text { Firm } \\
\text { heterogeneity } \\
\text { model }\end{array}$ & $\begin{array}{c}\text { Armington } \\
\text { model }\end{array}$ & $\begin{array}{c}\text { Firm } \\
\text { heterogeneity } \\
\text { model }\end{array}$ & $\begin{array}{c}\text { Armington } \\
\text { model }\end{array}$ & $\begin{array}{c}\text { Firm } \\
\text { heterogeneity } \\
\text { model }\end{array}$ \\
\hline USA & 5.1 & 4.0 & 17.1 & 12.3 & 9.0 \\
EU & 2.6 & 2.0 & 10.8 & 7.6 & 3.0 \\
Australia \& & 7.5 & 5.8 & 9.7 & 6.6 & 4.6 \\
N. Zealand & 10.4 & 7.5 & 13.5 & 9.3 & 5.7 \\
Japan & 8.3 & 5.7 & 12.2 & 7.8 & 5.5 \\
NIEs & 19.3 & 13.7 & 14.4 & 9.6 & 7.1 \\
China & 8.3 & 5.4 & 16.5 & 7.3 & 8.4 \\
ASEAN & 38.9 & 27.5 & 12.2 & 8.8 & 5.7 \\
India & 24.6 & 17.2 & 15.0 & 10.5 & 7.7 \\
Rest of Asia & 12.4 & 9.5 & 15.5 & 11.2 & 9.4 \\
Latin America & 14.2 & 11.0 & 8.5 & 5.9 & 4.3 \\
Africa & 6.9 & 5.2 & 10.5 & 7.3 & 5.3 \\
Rest of the World & 6.8 & 5.0 & 12.7 & 8.6 & 5.4 \\
Total & & & & & \\
\hline & & & & & \\
\hline
\end{tabular}

zation is 40 per cent stronger in the firm heterogeneity model than that in Armington model. In the new model with its particular parameters, the elasticities of world trade with respect to overall tariff, variable trade costs and fixed exporting costs are $0.13,2.5$ and 0.1 , respectively.

\section{Sensitivity Analysis}

A number of assumptions are made in model calibration to determine the values of some important parameters, like substitution elasticity between varieties $\sigma$, shape parameter firms $\gamma_{i}^{s}$, fixed trade costs $F_{i j}^{s}$ and variable trade costs $\tau_{i j}^{s}$. In this section I check the robustness of the simulation results in the above section to alternative assumptions about these parameters.

\section{(1) Substitution Elasticity between Varieties}

Empirical estimates of industrial markup ratios usually range from 10-20 per cent, ${ }^{17}$

${ }^{17}$ See, for example, Oliveira-Martins, Scarpetta and Pilat (1996). 
implying a much higher substitution elasticity $\sigma^{s}$ of 6-11 than that I choose in section III. However, some direct estimates of substitution elasticity between product varieties suggest lower values. For example, Broda and Weinstein (2006) estimate the elasticity between (10-digit Harmonized System) varieties for the US and find an average of 6.6 for 2715 for 2715 5-digit SITC sectors and 4.0 for 256 3 -digit SITC sectors. The more aggregated the sectors, the less substitutability between varieties. In viewof the mixed empirical evidence about the substitution elasticities, I conduct sensitivity analysis simulations for both higher and lower values of them. In the higher (lower) elasticity simulation, markup ratios are 0.05 smaller (higher) than their benchmark values in Table 1, rending the elasticity values ranging from 5-7.7 (3.9-5.0). In the sensitivity analysis simulations, the shape parameter $\gamma_{i}^{s}$ are kept same with that used in the benchmark simulations.

Table 6 presents the welfare and trade effects of the three trade liberalization simulations under alternative substitution elasticity values. It shows that the trade expansion and welfare gains of trade costs reduction are smaller under higher elasticities between varieties and larger under lower elasticity between varieties. The results also show that the effects of fixed trade costs reduction are very sensitive to the elasticity values. Under low (high) elasticity assumptions, the gain in global trade and welfare from fixed trade cost reduction would be 70 per cent higher (60 per cent lower) than that obtained from benchmark assumptions of substitution elasticity. The impact of elasticity values on the effects of tariff reduction are less significant, generally ranging from 4 per cent to 9 per cent for trade expansion and from 10 per cent to 20 per cent for welfare gains. The choices of different substitution elasticity values have only modest impact on the effects of reducing variable trade costs.

These findings are consistent with the theoretical prediction that the substitution elasticity between varieties has a negative effect on the elasticity of trade flows with respect to tariff and fixed trade costs (see equation (27)), as a higher substitution elasticity makes the extensive margin less sensitive to changes in trade barriers, damping the impacts of trade costs reduction on trade flows (Chaney, 2006). This property makes the firm heterogeneity CGE model distinctly different from Armington CGE model, in which an increase in Armington elasticity roughly causes the same magnitude of increase in the trade expansion and welfare.

\section{(2) Shape Parameter in Pareto Productivity Distribution}

In the firm heterogeneity model, the dispersion of firm productivity plays an 
Table 6. Welfare and Trade Effects under Alternative $\sigma^{s}$

\begin{tabular}{|c|c|c|c|c|c|c|}
\hline & \multicolumn{3}{|c|}{ Welfare (EV, bn US\$) } & \multicolumn{3}{|c|}{ Real Exports (\%) } \\
\hline & $\begin{array}{l}\text { Low } \\
\text { value }\end{array}$ & $\begin{array}{c}\text { Benchmark } \\
\text { value }\end{array}$ & $\begin{array}{l}\text { High } \\
\text { value }\end{array}$ & $\begin{array}{l}\text { Low } \\
\text { value }\end{array}$ & $\begin{array}{c}\text { Benchmark } \\
\text { value }\end{array}$ & $\begin{array}{l}\text { High } \\
\text { value }\end{array}$ \\
\hline \multicolumn{7}{|c|}{ Manufacturing Tariff Reduction } \\
\hline USA & 2.8 & 3.5 & 3.9 & 5.4 & 5.1 & 4.8 \\
\hline EU & 18.2 & 16.6 & 15.0 & 2.7 & 2.6 & 2.5 \\
\hline Australia\&N. Zealand & 2.3 & 2.2 & 2.0 & 7.8 & 7.5 & 7.1 \\
\hline Japan & 17.3 & 15.6 & 14.1 & 11.1 & 10.4 & 9.8 \\
\hline NIEs & 10.0 & 8.5 & 7.0 & 8.8 & 8.3 & 7.8 \\
\hline China & 6.5 & 5.3 & 4.3 & 20.4 & 19.3 & 18.2 \\
\hline ASEAN & 11.8 & 9.8 & 8.1 & 9.0 & 8.3 & 7.8 \\
\hline India & 6.5 & 5.9 & 5.3 & 41.0 & 38.9 & 36.9 \\
\hline Rest of Asia & 1.2 & 0.9 & 0.7 & 26.7 & 24.6 & 22.7 \\
\hline Latin America & -0.1 & 0.2 & 0.4 & 12.9 & 12.4 & 11.9 \\
\hline Africa & 1.9 & 1.8 & 1.7 & 14.8 & 14.2 & 13.6 \\
\hline Rest of the World & 4.7 & 4.8 & 4.8 & 7.2 & 6.9 & 6.6 \\
\hline Total & 83.5 & 75.0 & 67.2 & 7.2 & 6.8 & 6.5 \\
\hline \multicolumn{7}{|c|}{ Variable Trade Costs Reduction } \\
\hline USA & 29.7 & 32.8 & 35.3 & 17.2 & 17.1 & 17.0 \\
\hline EU & 128.0 & 128.2 & 128.3 & 10.8 & 10.8 & 10.8 \\
\hline Australia\&N. Zealand & 5.0 & 5.0 & 5.0 & 9.9 & 9.7 & 9.6 \\
\hline Japan & 11.3 & 11.7 & 11.9 & 13.7 & 13.5 & 13.3 \\
\hline NIEs & 22.3 & 21.3 & 20.5 & 12.4 & 12.2 & 12.0 \\
\hline China & 18.1 & 18.0 & 17.8 & 14.5 & 14.4 & 14.2 \\
\hline ASEAN & 39.4 & 32.7 & 28.3 & 19.7 & 16.5 & 14.6 \\
\hline India & 3.6 & 3.7 & 3.8 & 12.3 & 12.2 & 12.1 \\
\hline Rest of Asia & 2.3 & 2.3 & 2.2 & 15.5 & 15.0 & 14.7 \\
\hline Latin America & 27.4 & 27.0 & 26.8 & 15.5 & 15.5 & 15.4 \\
\hline Africa & 9.7 & 9.7 & 9.7 & 8.5 & 8.5 & 8.4 \\
\hline Rest of the World & 35.5 & 35.9 & 36.2 & 10.6 & 10.5 & 10.4 \\
\hline Total & 332.4 & 328.3 & 325.9 & 12.9 & 12.7 & 12.5 \\
\hline \multicolumn{7}{|c|}{ Fixed Exporting Costs Reduction } \\
\hline USA & 72.1 & 44.3 & 18.6 & 19.4 & 9.0 & -1.0 \\
\hline EU & 241.1 & 144.1 & 54.7 & 8.9 & 3.0 & -3.3 \\
\hline Australia\&N. Zealand & 9.3 & 5.5 & 2.0 & 10.5 & 4.6 & -1.3 \\
\hline Japan & 24.3 & 13.3 & 4.1 & 15.3 & 5.7 & -3.1 \\
\hline NIEs & 42.1 & 24.0 & 8.6 & 13.0 & 5.5 & -2.0 \\
\hline China & 33.0 & 18.6 & 6.1 & 16.6 & 7.1 & -1.8 \\
\hline ASEAN & 60.9 & 34.6 & 12.0 & 18.2 & 8.4 & -1.2 \\
\hline India & 6.8 & 3.8 & 1.3 & 13.7 & 5.7 & -1.7 \\
\hline Rest of Asia & 4.3 & 2.5 & 0.8 & 17.7 & 7.7 & -1.5 \\
\hline Latin America & 55.9 & 32.9 & 13.1 & 19.3 & 9.4 & 0.1 \\
\hline Africa & 16.6 & 9.7 & 3.4 & 9.0 & 4.3 & -0.5 \\
\hline Rest of the World & 65.7 & 38.7 & 14.3 & 11.4 & 5.3 & -0.7 \\
\hline Total & 632.2 & 372.0 & 139.2 & 12.9 & 5.4 & -2.1 \\
\hline
\end{tabular}


Table 7. Welfare and Trade Effects under Higher $\gamma_{i}^{s}$

\begin{tabular}{|c|c|c|c|c|c|c|}
\hline & \multicolumn{2}{|c|}{$50 \%$ tariff cut } & \multicolumn{2}{|c|}{$\begin{array}{l}\text { Variable trade } \\
\text { costs reduction }\end{array}$} & \multicolumn{2}{|c|}{$\begin{array}{l}\text { Fixed exporting } \\
\text { costs reduction }\end{array}$} \\
\hline & Higher $\gamma$ & Benchmark & Higher $\gamma$ & Benchmark & Higher $\gamma$ & Benchmark \\
\hline \multicolumn{7}{|l|}{ Welfare (EV, bn US\$) } \\
\hline USA & 4.5 & 3.5 & 36.5 & 32.8 & 75.1 & 44.3 \\
\hline EU & 21.3 & 16.6 & 139.7 & 128.2 & 236.6 & 144.1 \\
\hline Australia\&N. Zealand & 2.6 & 2.2 & 5.4 & 5.0 & 9.0 & 5.5 \\
\hline Japan & 20.6 & 15.6 & 14.0 & 11.7 & 26.5 & 13.3 \\
\hline NIEs & 10.6 & 8.5 & 24.0 & 21.3 & 42.1 & 24.0 \\
\hline China & 10.0 & 5.3 & 22.0 & 18.0 & 37.6 & 18.6 \\
\hline ASEAN & 13.0 & 9.8 & 41.6 & 32.7 & 58.7 & 34.6 \\
\hline India & 11.2 & 5.9 & 5.0 & 3.7 & 8.2 & 3.8 \\
\hline Rest of Asia & 1.8 & 0.9 & 2.9 & 2.3 & 4.5 & 2.5 \\
\hline Latin America & 2.2 & 0.2 & 31.3 & 27.0 & 55.0 & 32.9 \\
\hline Africa & 3.6 & 1.8 & 11.1 & 9.7 & 16.6 & 9.7 \\
\hline Rest of the World & 8.5 & 4.8 & 40.0 & 35.9 & 66.4 & 38.7 \\
\hline Total & 110.0 & 75.0 & 373.4 & 328.3 & 636.4 & 372.0 \\
\hline \multicolumn{7}{|l|}{ Real Exports (\%) } \\
\hline USA & 7.4 & 5.1 & 24.2 & 17.1 & 28.3 & 9.0 \\
\hline EU & 3.6 & 2.6 & 15.5 & 10.8 & 15.6 & 3.0 \\
\hline Australia\&N. Zealand & 10.9 & 7.5 & 14.4 & 9.7 & 16.6 & 4.6 \\
\hline Japan & 15.3 & 10.4 & 19.7 & 13.5 & 25.4 & 5.7 \\
\hline NIEs & 11.7 & 8.3 & 17.2 & 12.2 & 20.7 & 5.5 \\
\hline China & 28.2 & 19.3 & 20.7 & 14.4 & 26.2 & 7.1 \\
\hline ASEAN & 11.8 & 8.3 & 27.1 & 16.5 & 25.4 & 8.4 \\
\hline India & 58.8 & 38.9 & 17.8 & 12.2 & 21.7 & 5.7 \\
\hline Rest of Asia & 37.3 & 24.6 & 22.3 & 15.0 & 25.4 & 7.7 \\
\hline Latin America & 17.7 & 12.4 & 22.1 & 15.5 & 28.1 & 9.4 \\
\hline Africa & 19.9 & 14.2 & 12.3 & 8.5 & 13.1 & 4.3 \\
\hline Rest of the World & 9.7 & 6.9 & 15.3 & 10.5 & 17.3 & 5.3 \\
\hline Total & 9.9 & 6.8 & 18.4 & 12.7 & 20.4 & 5.4 \\
\hline
\end{tabular}

important role in determining the impact of trade barriers on trade flows. Table 7 presents the simulation results of a 50 per cent cut in global manufacturing tariffs obtained under the assumption that the shape parameters $\gamma_{i}^{s}$ are $1 / 3$ higher than their benchmark values in Table 1. It shows that the results are sensitive to the choice of productivity dispersion parameter. A 1/3 increase in shape parameters 
leads to 40-50 per cent higher global welfare gains and trade expansion under the simulation of tariff reduction. This sensitivity analysis simulation confirms that the shape parameter $\gamma_{i}^{s}$, rather than the substitution elasticity between varieties, is the key parameter governing the effects of trade liberalization in Melitz-type firm heterogeneity model.

\section{(3) Fixed Trade Costs}

The base year variable and fixed trade costs are calibrated based on the assumed 60 per cent share of firms selling in domestic market and the 0.6 elasticity of the extensive margin with respect to trade flow. To explore the sensitivity of model results to the size of fixed trade costs, I conduct two sets of sensitivity analysis. The first set reduces the base year share of firms selling in domestic market from 60 per cent to 45 per cent. This consequently raises base year fixed trading costs by $1 / 3$. As both the fixed domestic trading costs and fixed exporting costs are raised proportionally, the calibrated base year variable trade costs are not impacted by the increase of fixed trade costs. The second set of simulations raises the elasticity of the extensive margin with respect to trade flow from 0.6 to 0.8 , i.e. assuming the changes in extensive margin account for 80 per cent of the difference in export values across regions. Under this set of simulation, the base year fixed domestic trading costs are same with that in benchmark simulations, but both variable trade and fixed exporting costs are changed in calibration. In a supplementary table, available from the author upon request, the welfare effects of the three trade liberalization simulations under the two alternative assumptions about fixed costs are reported. The results are essentially unchanged for the three simulations. This is not surprising because the policy shocks imposed in the three simulations are all expressed as percentage changes relative to their baseline levels. Despite the differences in calibrated base year fixed trading costs, the first-round effects of tariff cut and trade cost reduction on trade are same between the benchmark simulations and the sensitivity analysis.

\section{Conclusions and Qualifications}

The recent developed models of international trade with heterogeneous firms have opened up a new way for empirical CGE models to better capture the economy-wide effects of trade liberalization. This paper builds a multi-region, multi-sector global CGE model with firm heterogeneity, monopolistic competition 
and fixed trade costs a la Melitz (2003) and calibrates it to GTAP database. Illustrative trade liberalization simulations using it demonstrate that introducing firm heterogeneity improves the ability of CGE model to capture the trade expansion and welfare effects of trade liberalization. However, some important limitations of this study should be mentioned. First, the aggregation of countries in the CGE model may lead to some biases in the calibration of trade costs. Unlike the Armington model, the elasticity of trade flows with respect to the total demand in destination market is greater than one in the Melitz model. Thus differences in market sizes play a larger role in determination of the trade pattern in the Melitz CGE model than the conventional CGE models. In this new model, the aggregation of some small economies to a single region, such as rest-of-the-world region, may be problematic because this aggregate region is actually numerous small disjointed markets rather than a large integrated market (Balistreri et al., 2007). A second limitation is the assumption of no free entry and exit, so that the total mass of potential firms in each sector is fixed and any adjustment in the extensive margin is solely due to the changes in the shares of firms engaged in a specific market. Thus the model's results may overestimate the changes in the shares of exporting firms following a policy shock and the associated productivity changes, but underestimate the variety gains brought by new entrants. A better description of the firm's entry and exit dynamic will be important for improving the performance of the model. Finally, the model can also be improved in the modeling of the trade and use of intermediate goods. Some micro evidence has shown that firms are heterogeneous in terms of their use of imported intermediate inputs, and trade liberalization can thereby boost trade through the extensive margin for importers of intermediate goods (Ramanarayanan, 2006). A more realistic treatment of firm's behavior in the use of intermediate inputs would make the CGE model potentially useful in explaining the rise of vertical integration and the rapid expansion of trade in intermediate goods over the last two decades.

\section{Acknowledgements}

The author thanks Peter Dixon, Thomas Hertel, d'Artis Kancs, Thomas Rutherford and Ashley Winston for helpful comments. The views expressed are those of the author and do not necessarily reflect those of Asian Development Bank.

Received 30 June 2007, Revised 13 March 2008, Accepted 8 April 2008 


\section{References}

Ardelean, Adina (2007) "How Strong is the Love of Variety?" mimeo, Purdue University. Arkolakis, Costas (2006) "Market Access Costs and the New Consumers Margin in International Trade," mimeo, University of Minnesota.

Armington, Paul S. (1969) "A Theory of Demand for Products Distinguished by Place of Production," IMF Staff Paper, 16(1), 159-178.

Balistreri, Edward J., Russell H. Hillberry and Thomas F. Rutherford (2007) "Structural Estimation and Solution of International Trade Models with Heterogeneous Firms," mimeo, Colorado School of Mines.

Bergoeing, Raphael and Timothy J. Kehoe (2001) "Trade Theory and Trade Facts," Staff Report 284, Federal Reserve Bank of Minneapolis.

Bernard, Andrew B. and Bradford Jensen (1999) "Exceptional Exporter Performance: Cause, Effect, or Both?," Journal of International Economics, 47(1), 1-25, February.

Bernard, Andrew and Bradford Jensen (2004) "Why Some Firms Export," The Review of Economics and Statistics, 86(2), 561-569.

Bernard, Andrew, J. Bradford Jensen, and Peter Schott (2006) "Trade Costs, Firms and Productivity." Journal of Monetary Economics, 53(5), 917-937.

Bernard, Andrew, Jonathan Eaton, J. Bradford Jensen, and Samuel Kortum (2003) "Plants and Productivity in International Trade," American Economic Review, 93(4), 12681290.

Broda, Christian and David E. Weinstein (2006) "Globalization and the Gains from Variety," Quarterly Journal of Economics, 121(2), 541-585.

Brown, Drusilla K. (1987) "Tariffs, the Terms of Trade, and National Product Differentiation," Journal of Policy Modeling, 9(3), 503-26.

Chaney, Thomas (2006) "Distorted Gravity: Heterogeneous Firms, Market Structure, and the Geography of International Trade," mimeo, University of Chicago.

Clerides, Sofronis K., Saul Lach and James R. Tybout (1998) "Is Learning by Exporting Important? Micro-Dynamic Evidence from Colombia, Mexico, and Morocco," The Quarterly Journal of Economics, 113(3), 903-947, August.

Debaere, Peter and Mostashari, Shalah. (2005) "Do Tariffs Matter for the Extensive Margin of International Trade? An Empirical Analysis," CEPR Discussion Papers 5260.

Del Gatto, Massimo, Giordano Mion, and Gianmarco I.P. Ottaviano (2006) “Trade Integration, Firm Selection and the Costs of Non-Europe" (June 2006). CEPR Discussion Paper No. 5730.

de Melo, Jaime, and Sherman Robinson (1992) "Productivity and Externalities: Models of Export-Led Growth." The Journal of International Trade and Economic Development, 1(1), 41-68.

Devarajan, Shantayanan and Sherman Robinson (2005) "The Influence of Computable General Equilibrium Models on Policy." in Frontiers in Applied General Equilibrium 
Modeling: In Honor of Herbert Scarf, ed. T.J. Kehoe, T.N. Srinivasan, and J. Whalley, pp. 341-377. Cambridge, UK: Cambridge University.

Dixon, Peter B. and Maureen T. Rimmer (2002) Dynamic General Equilibrium Modelling for Forecasting and Policy: a Practical Guide and Documentation of Monash, Contributions to Economic Analysis 256, North Holland Publishing Company, Amsterdam.

Dixon, Peter B. and Maureen T. Rimmer (2003) “The US Economy from 1992 to 1998: Historical and Decomposition Simulations with the USAGE Model," Centre of Policy Studies/IMPACT Centre Working Papers g-143, Monash University, Centre of Policy Studies/IMPACT Centre.

Eaton, Jonathan, Samuel Kortum, and Francis Kramarz (2004) "Dissecting Trade: Firms, Industries, and Export Destinations," American Economic Review, 94(2), 150-154.

Falvey, Rod, David Greenaway, and Zhihong Yu (2006) "Extending the Melitz Model to Asymmetric Countries." University of Nottingham Research Paper No. 2006/07.

Fujita, M., P. Krugman, and A. Venables (1999) The Spatial Economy: Cities, Regions and International Trade. MIT Press, Cambridge, MA.

Helpman, Elhanan, Marc Melitz, and Stephen Yeaple (2004) "Export Versus FDI with Heterogeneous Firms," American Economic Review, 94(1) 300-316.

Russell H. Hillberry, Michael A. Anderson, Edward J. Balistreri, and Alan K. Fox (2005) "Taste Parameters as Model Residuals: Assessing the 'Fit' of an Armington Trade Model," Review of International Economics, 13(5), 973-984.

Hummels, David and Peter J. Klenow (2005) "The Variety and Quality of a Nation's Exports," American Economic Review, 95(3), 704-723.

Kehoe, Timothy J. (2005) "An Evaluation of the Performance of Applied General Equilibrium Models on the Impact of NAFTA." in Frontiers in Applied General Equilibrium Modeling: In Honor of Herbert Scarf, ed. T.J. Kehoe, T.N. Srinivasan, and J. Whalley, pp. 341-377. Cambridge, UK: Cambridge University.

Kehoe, Timothy J. and Kim J. Ruhl (2003) "How Important Is the New Goods Margin in International Trade?," Staff Report 324, Federal Reserve Bank of Minneapolis.

Krugman, Paul (1979) "Increasing Returns, Monopolistic Competition and International Trade," Journal of International Economics, 9, 469-479.

Kuiper, Marijke and Frank van Tongeren (2006) "Using Gravity to Move Armington - An Empirical Approach to the Small Initial Trade Share Problem in General Equilibrium Models." Presented at the 9th Annual Conference on Global Economic Analysis, Addis Ababa, Ethiopia.

Lewis, Jeffrey D., Sherman Robinson, and Zhi Wang (1995) "Beyond the Uruguay Round: The Implication of an Asian Free Trade Area." China Economic Review, 7, 35-90.

Melitz, Marc J. (2003) "The Impact of Trade on Intra-Industry Reallocations and Aggregate Industry Productivity," Econometrica, 71(6), 1695-1725.

Melitz, Marc J. and Gianmarco I.P. Ottaviano (2005) "Market Size, Trade, and Productivity," NBER Working Paper No. 11393.

Oliveira Martins, Joaquim, Stefano Scarpetta, and Dirk Pilat (1996) "Mark-Up Ratios in 
Manufacturing Industries: Estimates for 14 OECD Countries," OECD Economics Department Working Papers 162, OECD Economics Department.

Ramanarayanan, Ananth (2006) "International Trade Dynamics with Intermediate Inputs," mimeo, University of Minnesota.

Roberts, Mark and James R. Tybout (1997) "The Decision to Export in Colombia: An Empirical Model of Entry with Sunk Costs," American Economic Review, 87(4), 545-64, September.

Yeaple, Stephen Ross (2005) "A Simple Model of Firm Heterogeneity, International Trade, and Wages," Journal of International Economics, 65(1), 1-20.

Yi, Kei-Mu (2003) "Can Vertical Specialization Explain the Growth of World Trade?," Journal of Political Economy, 111(1), 52-102, February.

van der Mensbrugghe, Dominique (2005) "LINKAGE Technical Reference Document," mimeo, Economic Policy and Prospects Group, The World Bank.

World Bank. Global Economic Prospects, 2002: Making Trade Work for the World's Poor, Washington D.C.: World Bank; 2001. 